\title{
AN APPLICATION OF ARCH AND ARCH-M MODELS TO STUDY INFLATION IN MEXICO FROM 1978 TO 1999
}

\author{
Norma A. Hernández Perales* \\ Tecnológico de Monterrey, Campus Monterrey \\ Russell Robins
}

A. B. Freeman School of Business, Tulane University

(Received 31 august 2001, accepted 18 march 2002)

\begin{abstract}
This paper analyzes the inflation process in Mexico, recognizing that the variance of inflation in Mexico changes over time (specifically in 1982, 1988, and 1994) and can be modeled following an ARCH (Autoregressive Conditional Heteroskedastic) model. We find that the inflation in Mexico follows an ARCH process from 1978 to 1999, and an ARCH-M process from 1989 to 1999. We also find that the process that better fits the conditional variance from 1978 to 1988 is an ARCH (2), and from 1989 to 1999 an ARCH (1). In both periods, the exchange rate is significant in the conditional variance, and in the mean of the inflation. The significant variables to explain the inflation from 1978 to 1988 are two inflation lags, the exchange rate, and the money supply (M1). These same variables, along with wages, are significant in explaining the inflation during 1989 to 1999.
\end{abstract}

\section{Resumen}

En este documento se analiza el proceso de inflación en México, reconociendo que la varianza de la inflación en México cambia a través del tiempo (específicamente en 1982, 1988 y 1994) y puede ser modelada a través de un modelo ARCH (Autorregresivo de Heterocedastícidad Condicional). Se observa que la inflación en México sigue un proceso de tipo ARCH de 1978 a 1999 y un proceso de tipo ARCH-M de 1989 a 1999. El proceso que mejor se ajusta a la varianza condicional de 1978 a 1988 es un $\mathrm{ARCH}(2)$ y de 1989 a 1999 un $\mathrm{ARCH}(1)$. En ambos periodos, el tipo de cambio es significativo en la varianza condicional y en la media de la inflación. Las variables que son significativas para explicar la inflación de 1978 a 1988 son los dos primeros rezagos de la inflación, el tipo de cambio y la oferta monetaria (M1). Estas variables, junto con los salarios, son significativas para explicar la inflación durante el periodo de 1989 a 1999.

JEL classification: C22, E31

Keywords: Conditional Variance, Inflation, ARCH process

* Instituto Tecnológico de Estudios Superiores de Monterrey, Campus Monterrey, Departamento de Finanzas, Av. Fundadores y Rufino Tamayo, Valle Oriente Garza García, N.L. México, Telephone (52)86256176, E-mail: nhernand@itesm.mx

The authors are grateful to the anonymous referees for their comments. 


\section{Introduction}

High volatility of inflation characterizes emerging countries. The high volatility of these countries is marked by frequent and sudden changes in variance. Important economic events in each of these countries, rather than global events, are found to be associated with high volatility. Bekaert and Harvey (1997), find that, on the average, the proportion of variance attributable to world factors is quite small for emerging markets.

While conventional time series and econometric models operate under the assumption of constant variance, the ARCH (Autoregressive Conditional Heteroskedastic) process introduced by Engle (1982) allows the conditional variance to change over time as a function of past errors, leaving the unconditional variance constant. This type of model behavior has already proven useful in modeling several different economic phenomena. Notably, Engle $(1982,1983)$ constructs models for the inflation rate, recognizing that inflationary uncertainty tends to change over time.

This paper studies the inflation process in an emerging market, Mexico, following ARCH and ARCH-M (in mean) models. We use Engle's model (1983) to develop inflation models for Mexico from 1978 to 1999. The models developed for Mexico inflation are a function of the following variables: money supply, exchange rate, and wages. Although other studies previously investigated the inflation process in Mexico using these variables, none of those studies used the $\mathrm{ARCH}$ or ARCH-M specifications to model the variance of inflation in Mexico.

Several studies describe the inflation process in Mexico during different periods of time. Arias and Guerrero (1988), using a VAR (Vector Autoregression) technique, show that the most significant variables in explaining the behavior of the inflation during 1970 to 1987 were the public sector prices, the exchange rate, and the money supply measured as M1. M1 was only significant from 1983 to 1987, and other variables such as the national minimum wage were not significant. A study by Guerrero (1984) developed an ARIMA (Autoregressive Integrated Moving Average) model using the methodology of Box, Jenkins and Tiao. In this model, Guerrero measured the inflationary effects of some economic events between 1970 and 1983. These relevant events were the implementation of the value-added tax (IVA, in Spanish, for impuesto al valor agregado) in 1980 and its modification in 1983, and the increases in nominal wages and fuel prices. Garcés (1999) analyzes the inflationary dynamic in Mexico from 1985 to 1998; his results seem to suggest that the significant variables in explaining inflation are: the first lag of inflation, the percent change in wages, the external prices measured as the percent change in CPI of the U.S., and (most significantly) the exchange rate. After identifying the variables that have an impact on the behavior of inflation, Garcés performs simulations to illustrate the dynamic properties of the model. 
Changes in the inflation level in 1982, 1988 and 1994, as well as high volatility characterized the inflation process in Mexico during the 1980's and 1990's, as can be seen in figure 1.

Figure 1. Quarterly Inflation Rate in Mexico (1978:03-1999:04).

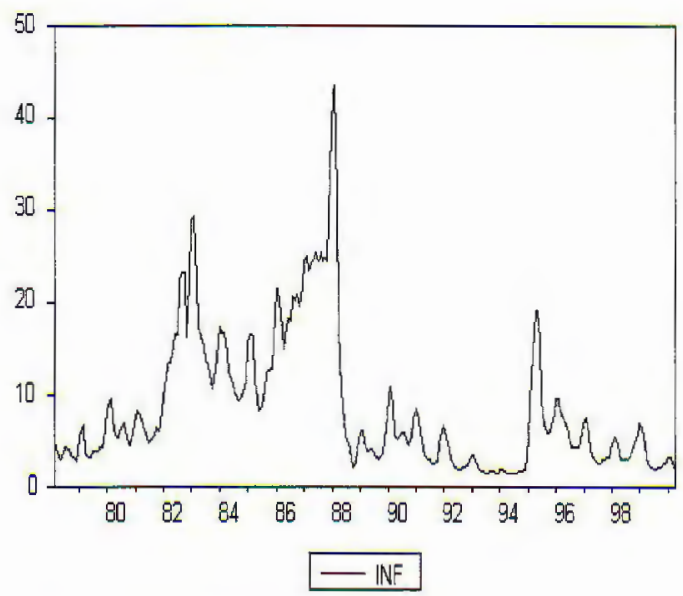

Data suggest that the inflation process in Mexico is not stable, and also show a time changing variance. We prove in this paper that inflation in Mexico follows an ARCH process from 1978 to 1999, and an ARCH-M process from 1989 to 1999. We find that the process that better fits the conditional variance from 1978 to 1988 is an ARCH-2, and from 1989 to 1999 an ARCH-1. In both periods, the exchange rate is significant in the conditional variance and in the mean of the inflation. The significance of the exchange rate suggests the importance of maintaining the stability of the exchange rate to keep under control the level and volatility of Mexico inflation. The significance of ARCH-M seems to suggest that the risk perceived by economic agents in the inflation process in Mexico is proxied by the conditional variance. In modeling the conditional variance, GARCH terms did not prove to be significant. This result clearly indicates that the variance process of inflation in Mexico has only short memory compared with the U.S.

The paper is organized as follows: the first section describes the ARCH and ARCH-M models, section two explains in detail the inflation models developed for Mexico, section three shows the econometric results and the stability tests performed with the models, section four explains the different policies taken by Mexican Central Bank to lower inflation during the 1980's and 1990's, and section five presents conclusions. 


\section{The ARCH and ARCH-M models}

\subsection{The ARCH-model}

The original tool for analyzing volatility forecasts is the ARCH model introduced by Engle (1982). The ARCH model is generalized to GARCH (generalized ARCH) by Bollerslev (1986), and is further extended by Nelson (1991) and Schwert (1990) to EGARCH (exponential). These are all models of conditional variance. In order to understand the difference between conditional and unconditional variance, we define $y_{t}$ as the return on an asset received in period $t$. Let E represent mathematical expectation. Then, the mean of the return can be called $\mu$

$$
\mathrm{E}\left[y_{t}\right]=\mu,
$$

where $\mu$ is the unconditional mean, which is not a random variable. The conditional mean, $m_{t}$, uses information from the previous period and can generally forecast more accurately than $\mu$. The conditional mean is given by:

$$
m_{t}=\mathrm{E}\left[y_{t} \mid F_{t-1}\right]=\mathrm{E}_{t-1}\left[y_{t}\right],
$$

where $m_{t}$ is a random variable depending on the information set $F_{t-1}$. Although $y_{t}-\mu$ can be forecast, $y_{t}-m_{t}=\varepsilon_{t}$ cannot, by using the information in $F_{t-1}$ alone.

The unconditional and conditional variances are defined, respectively, as:

$$
\begin{aligned}
\sigma^{2}=\mathrm{E}\left[y_{t}-\mu\right]^{2} & =\mathrm{E}\left[y_{t}-m_{t}\right]^{2}+\mathrm{E}\left[m_{t}-\mu\right]^{2}, \\
h_{t} & =\mathrm{E}_{t-1}\left[y_{t}-m_{t}\right] .
\end{aligned}
$$

Financial studies have typically focused on variance, $\sigma^{2}$, as the measure of volatility. The conditional variance potentially depends upon the informations set. The ARCH model asumes that investors with knowledge of $F_{t-1}$ will forecast more accurately the conditional variance, because the information imbedded in the error term of the previous period is taken into account, and by this way it is possible to obtain efficient estimators of the parameters.

Note that $\varepsilon_{t}^{2}-h_{t}$ cannot be forecast and may, therefore, be considered to be as a volatility surprise. Equation (4) is different from the first term on the right hand side of equation (3), implying that volatility is predictable; hence, $h_{t}$ is a random variable that depends upon recent information.

Engle (1982), suggests that use of an ARCH model may increase efficiency of the estimators of the parameters, devcloped the model to heteroskedasticity. This model allows the variance of a regression to change over time. The variance in one period is allowed to depend upon variables known from previous periods, including the disturbances. The model recognizes explicitly the difference between the conditional and unconditional variance; the conditional variance depends upon memory of disturbances, and other random variables in 
the conditioning set, while the unconditional variance may often be a constant, as traditionally assumed.

The ARCH model is preferred for modeling time-varying variance over the standard method in the literature of calculating a moving average of squared residuals. Examples include models of inflation, interest rates, and stock market returns. In modeling interest rates for emerging countries, is likely to find periods of high volatility (and large errors) followed by periods of low volatility (and small errors). In other words, a particular kind of heteroskedasticity is present when the variance of the regression error depends on the volatility of the error in the recent past. The ARCH model is sensitive, however, to departures from its hypothesis that the residuals of the regression model for inflation are uncorrelated. Consequently, it is important to carry out diagnostic tests on the residuals for the suitable model to ensure that the residuals are uncorrelated.

The model is explained in terms of an information set $\psi_{t}$ that includes all information available up to time $t$. Letting $y_{t}$ be the dependent variable, and $x_{t}^{\prime}$ be a vector of explanatory variables included in $\Psi_{t}$, the $p$-th order linear $\mathrm{ARCH}$ regression model formally is shown below:

$$
\begin{aligned}
& y_{t} \mid \Psi_{t-1} \sim \mathcal{N}\left(x_{t} \beta, h_{t}\right), \\
& h_{t}=\alpha_{0}+\alpha_{1} \varepsilon_{t-1}^{2}+\alpha_{2} \varepsilon_{t-2}^{2}+\cdots+\alpha_{p} \varepsilon_{t-p}^{2}+\alpha_{q} x_{t-1}, \\
& \varepsilon_{t}=y_{t}-x_{t} \beta .
\end{aligned}
$$

For different models, $h_{t}$ usually depends on the intercept and a weighted average of past squared errors, where the weights are assumed to be linearly declining. Also, $h_{t}$ might depend on other variables; in the case of Mexico, $h_{t}$ depends on the exchange rate.

\subsection{The ARCH-M model}

In the ARCH-M model, introduced by Engle, Lilien and Robins (1987), not only the heteroskedastic disturbances, but also the standard deviation of each observation affect the mean of that observation. In the case of Mexico, one would expect that the level of inflation will be proportional to the level of the risk perceived by the economic agents. The ARCH-M model allows us to include the conditional variance on the right hand side of the regression equation. In this model, an increase in the conditional variance will be associated with an increase or decrease in the conditional mean of $y_{t}$.

Then, the ARCH-M model can be written:

$$
\begin{aligned}
& y_{t} \mid \Psi_{t-1} \sim \mathcal{N}\left(x_{t} \beta+\delta\left(h_{t}\right)^{1 / 2}, h_{t}\right) \\
& h_{t}=\alpha_{0}+\alpha_{1} \varepsilon_{t-1}^{2}+\alpha_{2} \varepsilon_{t-2}^{2}+\cdots+\alpha_{p} \varepsilon_{t-p}^{2}+\alpha_{q} x_{t-1} \\
& \varepsilon_{t}=y_{t}-x_{t} \beta
\end{aligned}
$$

As in the ARCH model, $h_{t}$ depends upon the intercept and a weighted average of past squared crrors. 


\section{Test for ARCH and ARCH-M models}

Following the model developed by Engle (1983) for the U.S. inflation, we develope scveral appropriate inflation models for Mexico. These models cover different periods of time since 1978, which were characterized by stability in the inflation rate and in the exchange rate, until periods of high volatility such as 1982, 1987, and 1994. We develop two models; a first model from 1978 to 1988, thereby the pre-debt crisis period (1978-1982) and the high volatility inflation period (1983-1987) are included. The second model spais 1989 to 1999 , thereby including the highly stable economic period (1989-1994), and after the devaluation crisis (1995-1999). The models take into account the monthly observations of the quarterly percent changes of the independent variables, as we explain in detail below. We use the data series published on the official website of the Mexican Central Bank.

In both models, we have two lags in quarterly inflation, with the independent variables as: the quarterly percent change in the montlyly average of the exchange rate, the quarterly percent change in moncy supply (M1), and the annual average of the quarterly percent change of the wages index. The conditional variance is modeled following an ARCH process and takes into account the exchange rate.

Some differences in the significance of the coefficients are observed when we performed a least squares (LS) model instead of an ARCH model: a) the coefficient of the exchange rate appears more significant with the ARCH model from 1978:03 to 1988:12 than with the LS model; b) the coefficient of the quarterly percent change of wages, while not significant with LS, seems to be significant with ARCH from 1989:01 to 1999:04; c) the money supply appears more significant (1978 to 1988, and 1989 to 1999) with $\mathrm{ARCH}$ specification than with the LS model.

We tested other variables to find a better model. We generated dummy variables in the periods of devaluation crisis, and lags in the inflation rate and exchange rate, and took into account other $\mathrm{ARCH}$ and $\mathrm{GARCH}$ specifications to model the conditional variance, but no significant improvement was found. Also, we started testing a model that includes the entire period (1978:03 to 1999:04), but a structural change was found in december of 1988 . Therefore, we tried to find modcls that fit for each of the two periods (1978:03 to 1988:12, and 1989:01 to 1999:04). The models and definitions of the independent variables are shown below:

\section{3.a Model for the period from 1978:03 to 1999:04}

$$
\begin{aligned}
I N F_{t} & =\alpha_{0}+\alpha_{1} I N F_{t-1}+\alpha_{2} I N F_{t-2}+\alpha_{3} E R M A P_{t}+\alpha_{4} M 1 P_{t} \\
& +\alpha_{5} R W A G E A V_{t}+\varepsilon_{t}, \\
h_{t} & =\beta_{0}+\beta_{1} \varepsilon_{t-1}^{2}+\beta_{2} E R M A P_{t-1} .
\end{aligned}
$$


3.b Model for the period from 1978:03 to 1988:12

$$
\begin{aligned}
I N F_{t} & =\alpha_{0}+\alpha_{1} I N F_{t-1}+\alpha_{2} I N F_{t-2}+\alpha_{3} E R M A P_{t}+\alpha_{4} M 1 P_{t} \\
& +\alpha_{5} R W A G E A V_{t}+\varepsilon_{t}, \\
h_{t} & =\beta_{0}+\beta_{1} \varepsilon_{t-1}^{2}+\beta_{2} \varepsilon_{t-2}^{2}+\beta_{3} E R M A P_{t-1} .
\end{aligned}
$$

\section{3.c Model for the period from 1989:01 to 1999:04}

$$
\begin{aligned}
I N F_{t} & =\alpha_{0}+\alpha_{1} I N F_{t-1}+\alpha_{2} I N F_{t-2}+\alpha_{3} E R M A P_{t}+\alpha_{4} M 1 P_{t} \\
& +\alpha_{5} R W A G E A V_{t}+\alpha_{6}\left(h_{t}\right)^{1 / 2}+\varepsilon_{t}, \\
h_{t} & =\beta_{0}+\beta_{1} \varepsilon_{t-1}^{2}+\beta_{2} E R M A P_{t-1}
\end{aligned}
$$

where: $I N F=$ Quarterly inflation rate; $E R M A P=$ Quarterly percent change in the monthly average exchange rate; $R W A G E A V=$ Annual average of the quarterly percent change of the wages index; $M 1 P=$ Quarterly percent change in the money supply. The model includes the exchange rate because we observed that an increasing in inflation (figure. 2) is always led by a devaluation.

Figure 2. ERMAP and INF (1978:03-1999:04)

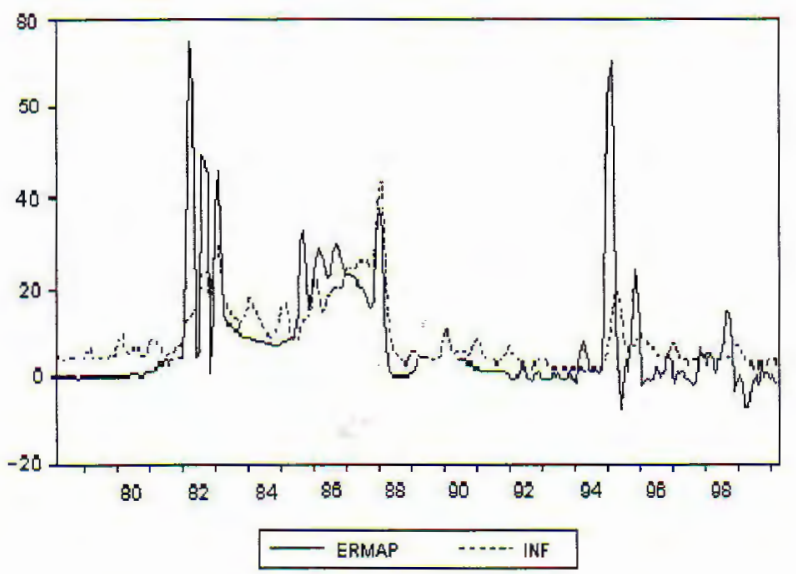

Money supply and wages, are included in the model because of the relationship that these variables have with inflation. It is important to recall that the monetary policy has been an important variable for the Mexican government to influence the interest rate and the exchange rate, and eventually the general price level. Wages and inflation are anchored through the wage and price control agreement dating from the government of Salinas. The behavior of the two variables previously mentioned according to inflation rate is shown in figures 3 and 4 . 
Figure 3. INF and M1P (1978:03-1999:04)

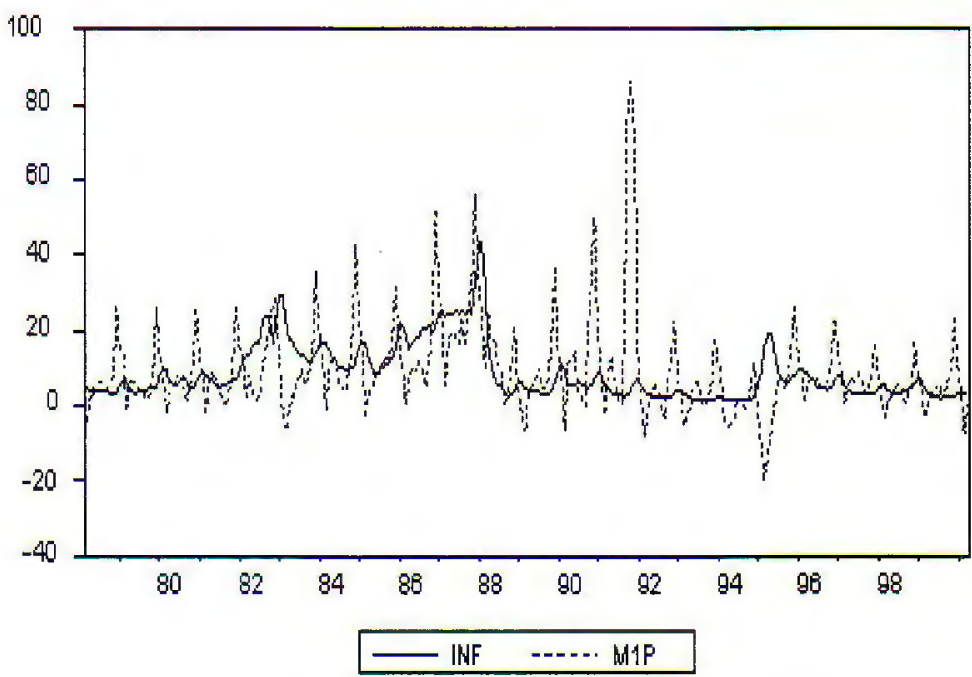

Figure 4. RWAGEAV and INF (1978:03-1999:04)

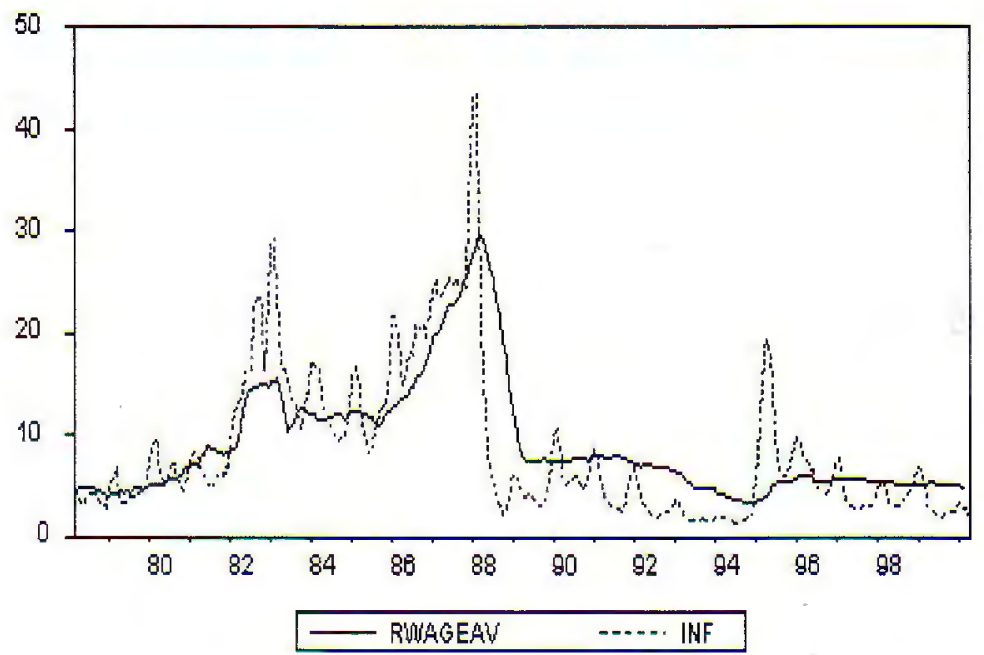




\section{Results}

First, we tested variables for stationarity using the Augmented Dickey-Fuller (ADF) test by means of the percentage changes of the independent variables defined in the model. The results are shown in table 1.

Table 1. Augmented Dickey-Fuller Test

\begin{tabular}{|c|c|}
\hline Variable & ADF Statistic \\
\hline iMoney Supply (MIP) & $-5.7931^{* * *}$ \\
Exchange Rate (ERMAP) & $-3.8653^{* * *}$ \\
Inflation Rate (INF) & $-3.2098^{* *}$ \\
Wages Rate (RWAGEAV) & $-2.6324^{*}$ \\
\hline
\end{tabular}

*** Indicates rejection of the null hypothesis of non-stationarity at the $1 \%$ level of significance.

** Indicates rejection of the null hypothesis of non-stationarity at the $5 \%$ level of significance.

* Indicates rejection of the null hypothesis of non-stationarity at the $10 \%$ level of significance.

To check the stationarity of the series, the ADF test was performed for 1978:03 to 1999:04.

Since the variables are stationary, it is possible to perform the regressions to model Mexico inflation. We tried to find a model for the entire period (1978:031999:04), but, due to the structural change shown in the model (a), we decided to replace it by models (b) and (c) (see table 2).

Model (b) covers the period between 1978 and 1988, which includes the previous years to the debt crisis. As we can see in the table 2, there are two significant inflation lags, indicating an inertia in the inflation process. Also significant are the exchange rate and the money supply. These results support the findings of Arias and Guerrero (1988). Their results show that the most significant variables to explain the inflation in Mexico from 1970 to 1987 were the public sector prices, the exchange rate, and the money supply, being the last the most significant from 1983 to 1987. Although, the exchange rate coefficient in our model is small, it is significant, probably due to the objective of the government of maintaining a falling exchange rate despite the high inflation level from 1982 to 1988 . Wages are not significant in our model, as in the Arias and Guerrero study.

In model (c) of the table 2, which spans 1989 to 1999, we find the same variables significant, but with the wages also significant. These results are consistent with those of Garcés (1999), who found that the significant variables in explaining Mexico inflation from 1985 to 1998 are wages and the exchange rate. Model (c) shows, as well, minor coefficients for the exchange rate and the money supply compared with their respective coefficients in the previous model 
of 1978 to 1988 . The minor coefficient of the exchange rate is perhaps explained by the daily falling of the exchange rate, between 1989 and 1994, and the floating band exchange rate established after the December 1994 devaluation by the government of Zedillo. The minor coefficient of the money supply is probably explained by the restrictive monetary policies to control inflation during the governments of Salinas de Gortari and Zedillo. The wage coefficient, from 1989 to 1999 , although small is significant, perhaps since the government maintained control over wages according to inflation through the wage and price control agreement.

In contrast with other models developed for Mexico, ARCH terms and the exchange rate variables are included in the conditional variance equation in models (b) and (c) from table 2. The results from model (b) show that the ARCH-1, ARCH-2, and the exchange rate are significant in the conditional variance, meaning that, it is possible to obtain estimators more efficient than those estimated with LS or ARMA (Autoregressive Moving Average) models. The results from model (c) show that the $\mathrm{ARCH}-1$ and the exchange rate are significant in the conditional variance. In this model, the ARCH-M term is also significant; this result clearly means that the inflation risk perceived by the economic agents in Mexico is proxied by the conditional variance.

To test whether the conditional variance follows a GARCH process, we tried adding GARCH terms in the conditional variance equation, but no significant coefficients were obtained. The lack of significance of the GARCH terms indicates that the variance process of Mexico inflation has only short memory. This result is opposite to the findings that the conditional variance in U.S. follows a GARCH process, and therefore is a process with long memory. In both models (b) and (c), we found the exchange rate significant in the conditional variance and in the mean of the process. These results suggest the importance in Mexico of having stability in the exchange rate to control the volatility and level of inflation.

To determine whether the models are stable during the time periods defined for each one, we use the Likelihood Ratio Test and then verify the stability of the parameters. We choose to test the structural change when a shift in government policies ocurred, in general, we were thinking in the case when an increase in inflation lead a devaluation or viceversa. The first structural change tested was in model (a) of table 3, when in December 1987 a devaluation of $18 \%$ of the peso occurred and caused an increase in inflation around $31 \%$ between December 1987 and March 1988. The rejection of the null hypothesis in model (a) of the table 3 seems to suggest the need of different models for each period in study. To address the structural change shown in model (a), we developed one model for the period previous to December 1988 and another model to the period starting at January 1989. These models match those explained in table 2. 
Table 2. Results of the models performed: a)entire sample 1978:03 - 1999:04;

b)sub-pcriod 1978:03 - 1988:12 and c) in sub-period 1989:01 -1999:04.

\begin{tabular}{|c|}
\hline $\begin{array}{c}\text { a) } I N F_{t}=\alpha_{0}+\alpha_{1} I N F_{(t-1)}+\alpha_{2} I N F_{(t-2)}+\alpha_{3} E R M A P_{t}+\alpha_{4} M 1 P_{t}+\alpha_{5} R W A G E A V_{t}+\varepsilon_{t} \\
h_{t}=\beta_{0}+\beta_{1} \varepsilon_{t-1}^{2}+\beta_{2} E R M A P(t-1)\end{array}$ \\
\hline $\begin{array}{c}\text { b) } I N F_{t}=\alpha_{0}+\alpha_{1} I N F_{(t-1)}+\alpha_{2} I N F_{(t-2)}+\alpha_{3} E R M A P_{t}+\alpha_{4} M 1 P_{t}+\alpha_{5} R W A G E A V_{t}+\varepsilon_{t} \\
h_{t}=\beta_{0}+\beta_{1} \varepsilon_{t-1}^{2}+\beta_{2} \varepsilon_{t-2}^{2}+\beta_{3} E R M A P_{(t-1)}\end{array}$ \\
\hline $\begin{array}{c}\text { c) } I N F_{t}=\alpha_{0}+\alpha_{1} I N F_{(t-1)}+\alpha_{2} I N F_{(t-2)}+\alpha_{3} E R M A P_{t}+\alpha_{4} M 1 P_{t}+\alpha_{5} R W A G E A V_{t}+\alpha_{6}\left(h_{t}\right)^{1 / 2}+\varepsilon_{t} \\
h_{t}=\beta_{0}+\beta_{1} \varepsilon_{t-1}^{2}+\beta_{2} E R M A P(t-1)\end{array}$ \\
\hline
\end{tabular}

\begin{tabular}{|c|c|c|c|c|c|c|c|}
\hline \multicolumn{7}{|c|}{ a) $1978: 03$ to $1999: 04$. } & \\
\hline & $\alpha_{0}$ & $\alpha_{1}$ & $\alpha_{2}$ & $\alpha_{3}$ & $\alpha_{4}$ & $\alpha_{5}$ & \\
\hline Coef. & -0.3084 & 1.3929 & -0.5796 & 0.0666 & 0.0667 & 0.0988 & \\
\hline Std. error & 0.0773 & 0.0361 & 0.0348 & 0.0050 & 0.0035 & 0.0126 & \\
\hline T stat. & -3.9873 & 38.5047 & -16.6185 & 13.2112 & 19.0121 & 7.8178 & \\
\hline$h_{t}$ & $\beta_{0}$ & $\beta_{1}$ & $\beta_{2}$ & & & & \\
\hline Coef & 0.3443 & 1.1000 & 0.0444 & & & & $r^{2} 0.9546$ \\
\hline Std. error & 0.0561 & 0.2004 & 0.0132 & & & & $\mathrm{r}^{2}$ adj 0.9533 \\
\hline T stat. & 6.1346 & 5.4868 & 3.3489 & & & & DW 1.8250 \\
\hline
\end{tabular}


Table 2. Results of the models performed: a)cutire sample 1978:03 - 1999:04; b)sub-period 1978:03 - 1988:12 and c) in sub-period 1989:01 -1999:04. (continued)

\begin{tabular}{|c|c|c|c|c|c|c|c|c|}
\hline \multicolumn{9}{|c|}{ b) $1978: 03$ to $1988: 12$} \\
\hline & $\alpha_{0}$ & $\alpha_{1}$ & $\alpha_{2}$ & $\alpha_{3}$ & $\alpha_{4}$ & $\alpha_{5}$ & & \multirow{8}{*}{$\begin{array}{c}\mathrm{r}^{2} 0.9445 \\
\mathrm{r}^{2} \text { adj } 0.9403 \\
\mathrm{DW} 1.8231\end{array}$} \\
\hline Coef. & 0.3467 & 1.2215 & -0.3909 & 0.0880 & 0.0965 & -0.0242 & & \\
\hline Std. error & 0.1638 & 0.0735 & 0.0768 & 0.0125 & 0.0090 & 0.0249 & & \\
\hline $\mathbf{T}$ stat. & 2.1162 & 16.6173 & -5.0842 & 6.9960 & 10.6390 & -0.9715 & & \\
\hline$h_{t}$ & $\beta_{0}$ & $\beta_{1}$ & $\beta_{2}$ & $\beta_{3}$ & & & & \\
\hline Coef. & 0.0973 & 0.5025 & 0.6419 & 0.1032 & & & & \\
\hline Std. crror & 0.0745 & 0.2004 & 0.1928 & 0.0292 & & & & \\
\hline T stat. & 1.3057 & 2.4827 & 3.3296 & 3.5321 & & & & \\
\hline \multicolumn{9}{|c|}{ c) $1989: 01$ to $1999: 04$} \\
\hline & $\alpha_{0}$ & $\alpha_{1}$ & $\alpha_{2}$ & $\alpha_{3}$ & $\alpha_{4}$ & $\alpha_{5}$ & $\alpha_{6}$ & \\
\hline Coef. & -0.4163 & 1.3078 & -0.5446 & 0.0377 & 0.0164 & 0.0809 & 1.2083 & \\
\hline Std. error & 0.3229 & 0.0387 & 0.0376 & 0.0068 & 0.0022 & 0.0379 & 0.4927 & \\
\hline T stat. & -1.3821 & 33.7202 & -14.4622 & 5.5128 & 7.3660 & 2.1347 & 2.4522 & \\
\hline$h_{t}$ & $\beta_{0}$ & $\beta_{1}$ & $\beta_{2}$ & & & & & \\
\hline Coef. & 0.1238 & 0.5965 & 0.02152 & & & & & ${ }^{2} 0.9604$ \\
\hline Std. crror & 0.0337 & 0.2208 & 0.00708 & & & & & $\mathrm{r}^{2}$ adj 0.9573 \\
\hline T stat. & 3.6662 & 2.7006 & 3.03839 & & & & & DW 1.7991 \\
\hline
\end{tabular}

$I N F=$ Quarterly inflation rate.

$E R M A P=$ Quarterly percent change in the monthly average exchange rate.

RWAGEAV = Annual average in the quarterly percent change in wages

$M 1 P=$ Quarterly percent change in the money supply

Source: Own calculations from Manufacturing Census, 1975 and 1998. 
In model (b) of table 3, we suspect a structural change in December 1982 because of a peso devaluation of about $15 \%$ and the inflation upheaval of $29 \%$ that occurred in the next three months. We also tested December 1983 because of the inflation inestability and the slipping of the exchange rate during that year. Acceptance of the null hypothesis confirms the stability of the model to the sub-period (1978-1988).

The last structural change tested was after the $65 \%$ devaluation of 1994 , when Mexican interest rates rose and a high inflation level of around $15 \%$ was recorded after a stable low inflation rate between 1993 and 1994 . We should note that Mexico was experiencing $1.5 \%$ levels of quarterly percent inflation during the last two years of Salinas de Gortari government. The rejection of the null hypothesis indicates a structural change at April 1995, because of the high inflation level attained in the months following the devaluation of the peso in december 1994.

The results shown in table 3 suggest: first, the model (b) from 1978:03 to 1988:12 is stable during that sub-period; second, the model (c) from 1989:01 to 1999:04 shows a structural change after the devaluation crisis of december 1994 . Because of the structural change in this model, we ran separate regressions before and after the devaluation crisis. Our results suggest that the coefficients of the variables change, but their significance does not. We observe that the ARCH-M effect is greater after the crisis than before it, perhaps reflecting the inestability and risk that the economic agents perceived after the devaluation of December 1994. The coefficient of the money supply (M1) is greater after December 1994 than before it, as well, this last result can be explained by the decision of the Mexican authorities to modify, during the first half of 1995, the monetary policy from one based solely on quantitative targets on monetary aggregates to one where they could influence interest rate levels.

Table 3. Stability Tests.

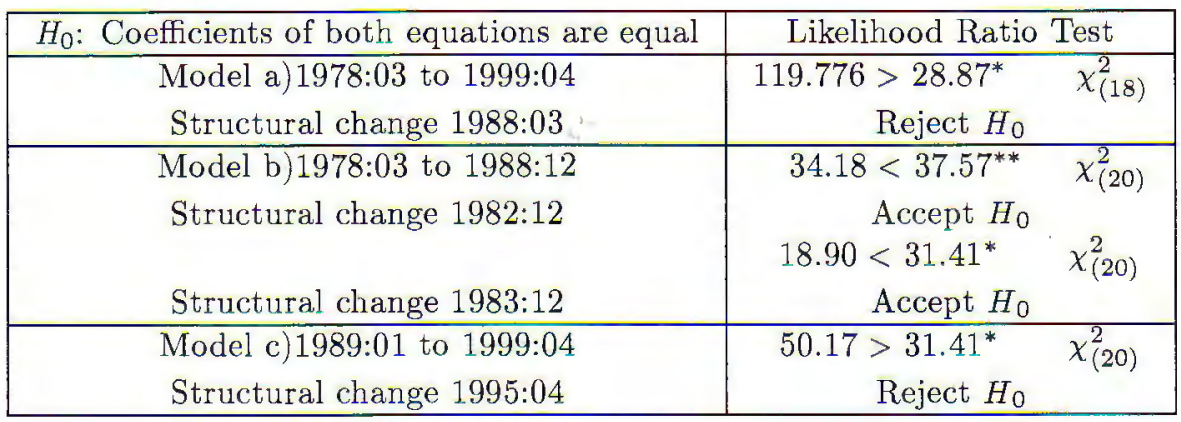

$* \chi_{\text {crit }}^{2}$ at $5 \%$.

$* * \chi_{c r i t}^{2}$ at $1 \%$. 


\section{Mexico macroeconomic adjustments: 1983 to 1999}

The periods studied in this paper are: a) the pre-debt crisis period, from 1978 to 1982 , which was featured by expansionary fiscal and monetary policies. This kind of policies were accompanied with an inflow of foreign loans to the public sector; b) the period between 1983 and 1987, when the government made serious attempts to correct domestic economic imbalances in order to fight high inflation; c) the next period, from 1988 to 1994, was characterized by a substantial improvement in economic conditions until the crisis of 1994; and d) the post-devaluation crisis period, 1995-1999, characterized by tight monetary policy and a floating exchange rate.

The debt crisis that began in August 1982 marked a turning point for the Mexican economy. Inflation soared, and four decades of uninterrupted growth came to an end. These events induced drastic changes in government policy. The De la Madrid government (1982-1988) adopted a strategy based on macroeconomic stabilization and the transformation of a highly regulated and protected economy into a market-oriented economy.

At this time, Mexico adopted a major adjustment program to stabilize the economy. From 1983 to 1987, fiscal and monetary policies were tightened, with particular emphasis on fiscal corrections. As one of the early achievements, the primary fiscal balance, defined as the overall cash balance of the public sector excluding interest payments and exchange losses, moved from a deficit of $5 \%$ of GDP in 1983 to a surplus of $5 \%$ in 1987 ; with $80 \%$ of the correction coming from reduced expenditures. This fiscal effort, however, was offset by high inflation: the average annual inflation rate was $89 \%$, and interest rates were correspondingly high. As investors withdraw their capital and new foreign loans to Mexico were curtailed severely, the government increased its reliance on monetary financing. Inflation increased sharply and the economy experienced a balance of payments crisis that ended with a major depreciation of the Mexican peso.

Domestic imbalances were exacerbated by the collapse of oil prices in the mid-1980's, the unwillingness of foreign creditors to extend further credits, and a large transfer of resources abroad to service the external debt at the high real interest rates prevailing in international markets. During this period, from 1983 to 1988 , the Mexican economy experienced the lowest economic growth rate since the early 1950 's. In December 1987, Mexico introduced a comprehensive economic program to correct imbalances, and, in particular, to sharply reduce the inflation rate. Fiscal policies were tightened further, and a wide-ranging wage, price, and exchange rate freeze was introduced.

The administration of Salinas de Gortari further refined the prior administration's economic strategy, emphasizing macroeconomic stabilization and structural reform. The stabilization strategy was based on macroeconomic programs that included tight fiscal and monetary policies, and a revised wage and price control agreement among government, firms and unions. The different sectors agreed to distribute the social cost of adjustment more evenly than in 
the previous years. These stabilization policies were designed to increase the primary balance in the public sector, to reduce domestic credit, and to constrict peso/dollar exchange rate devaluation to further reduce inflation.

The renegotiation of Mexico's foreign debt, signed in 1990, allowed for debt and debt service reduction packages. The comprehensiveness of the debt reduction package convinced international investors that the renegotiations were sound, and that thereafter Mexico would be in a position to meet all scheduled debt service obligations on newly contracted debt. The renegotiation was followed very rapidly by a sharp reduction in the risk premium and by significant inflows of foreign direct and portfolio investment.

Before the December 1994 devaluation, Mexico's exchange rate was essentially pegged to the U.S. dollar, although, Mexico permitted its exchange rate to fluctuate within a band whose weak-side edge devalued at 0.0004 pesos/dollar. With this band, the Mexican Central Bank could enact expansionary or contractionary monetary policies and still maintain exchange rate credibility. To maintain inflows of foreign capital, real interest rates began to increase starting in 1992, even though nominal rates were falling at this time. During the early 1990 's, the Mexican Commercial Banking system did not, at least by developed country standards, behave very competitively. Spreads between cost of funds and loan rates were large. Bank lending rates were typically very high in comparison to the developed countries standards. But increases in real rates made it particularly difficult for some firms to compete with foreign producers from countries where financial costs were lower.

To take advantage of the consumption boom of the early 1990's, Mexican financial institutions issued many credit cards to the wrong debtors. A dynamic exacerbated by the fact that the reporting of consumer credit records was relatively sketchy and unorganized in Mexico. Therefore, defaults became common.

Mexico simultaneously issued short-term peso denominated debt (Cetes) and short-term dollar indexed debt (Tesobonos), but as 1994 progressed, the country radically altered the currency configuration of its short-term debt so as to strengthen the peso. In January 1994, the dollar value of outstanding Cetes was $\$ 12.9$ billion, compared with $\$ 302$ million in Tesobonos. By november, outstanding Cetes had fallen to $\$ 7.27$ billion, while Tesobonos had risen to $\$ 11.6$ billion. Mexico's increased issuance of Tesobonos may also be seen as making its exchange rate policy credible by imposing a clear and obvious fiscal penalty for devaluation. The fact that the Tesobono maturity schedule signified obligations in early 1995 that were considerably in excess of Mexican dollar reserves, may have triggered individual investors to convert their Tesobono to avoid being among those left out of convertibility.

The crisis of 1994 began with a devaluation that triggered a run on the currency. Foreign currency reserves fell markedly, and Mexican interest rates rose rapidly, thus the peso/dollar exchange rate reached levels that advocates of Mexican devaluation found appropriate. 
With the aftermath of the 1994 devaluation of the peso, Mexico's economic policy makers faced three immediate challenges: a) to conduct an orderly macroeconomic adjustment in response of the steep reduction of capital inflows; b) to refinance short-term dollar denominated public debt by approximately $\$ 30$ billion; c) to maintain the solvency of the banking sector and protect depositor's savings.

The Mexican government implemented several measures in 1995 to address following challenges: a) to contain the inflationary effect of the devaluation, the government followed a tight monetary policy; b) the government through Mexican Central Bank pushed interest rates from 16\% in December 1994 to $86 \%$ in March 1995; and c) to ensure an orderly adjustment of the current account, the government tightened fiscal policy considerably.

In terms of the monetary policy followed, it is also important to note the implementation in 1996 of the "short" used by the Mexican Central Bank that makes this policy a nominal anchor of the economy. The accumulation of international reserves by the Central Bank also contributes to the exchange rate stability in this period. Consistent with the above, the Central Bank established as an intermediate target a ceiling on the growth of the monetary base for each year. The discretionary monetary policy action, along with the agreement with the International Monetary Fund (IMF), regarding a strong adjustment program and the availability of the Exchange Stabilization Fund, broke the sharp tendency towards depreciation that the peso showed during the first quarter of 1995. With this same strategy, the monetary authority achieved to stabilize inflationary expectations, and soundly to reduce the monthly infation rates. By May 1995, the devaluation of the peso and inflationary expectations stopped, which led to a reduction in nominal and real interest rates.

\section{Conclusions}

This paper proves that ARCH and ARCH-M models can be used to model the inflation process in Mexico, a country that experienced high volatility and shifts in inflation levels during the 1980's and 1990's. The significant independent variables that explain the inflation over the entire period of study (march 1978 april 1999) are the money supply, the peso/dollar exchange rate, and two lags of inflation. For the sub-period from 1989 to 1999, the coefficients of the wages and the ARCH-M term are also significant in explaining inflation in Mexico. This result clearly indicates that the risk perceived by economic agents is proxied by the conditional variance and that can be measured through the ARCH-M term. In the conditional variance equation, only $\mathrm{ARCH}$ terms are significant, from 1978 to 1988 the ARCH-2 term is significant, and from 1989 to 1999 only the ARCH-1 term is significant. The fact that only the ARCH terms are significant suggests that the inflation process in Mexico has only a short memory. This result contrasts with findings for the U.S. inflation process, that shows a long memory, as GARCH terms in the conditional variance equation reveal.

The importance of having a stable peso/dollar exchange rate to keep the volatility and level of the inflation in Mexico under control is shown by the 
significance of the coefficient of the exchange rate in the mean and in the conditional variance of the inflation for the period and subperiods studied (1978 to 1999). The floating exchange rate policy established by Zedillo apparently has become a very important element in keeping the inflation rate and the inflation volatility under control in Mexico.

Finally, as we expected, the money supply proved to be significant in the entire sample, perhaps because the policy followed by Mexican Central Bank is to remain in a position to react quickly to inflationary shocks and to adjust its monetary policy to influence the behavior of the interest rates in the pursuit of on inflation target.

\section{References}

Aggarwall, R., C. Inclan and R. Leal (1999), Volatility in Emerging Stock Markets, Journal of Financial and Quantitative Analysis, 34, pp. 33-55.

Arias, L., and V. Guerrero (1988), An Econometric Study of Mexico's Inflation 1970-1987, Banco de Mexico, Research No. 65.

Bailey, W., and Y.P. Chung (1995) Exchange Rate Fluctuations, Political Risk, and Stock Markets Returns: Some Evidence from an Emerging Market, Journal of Financial and Quantitative Analysis, pp. 541-561.

Bekaert, G., and C.R. Harvey (1997), Emerging Equity Market Volatility, Journal of Financial Economics 43, pp. 29-77.

Bollerslev, T. (1986), Generalized Autoregressive Conditional Heteroskedasticity, Journal of Econometrics, pp. 307-327.

Bollerslev, T., C. Ray, and K. Kroner (1992), ARCH Modeling in Finance, Journal of Econometrics 52, pp. 5-59.

Carstens, A. G, and A. Werner (1999), Mexico's Monetary Policy Framework under a Floating Exchange Rate Regime, Banco de Mexico, Direccion General de Investigacion Economica, Documento de Investigacion No. 9905

Cosimano, T. F., and D. W. Jansen (1988), Estimates of the Variance of U.S. Inflation based upon the ARCH Model: A comment, Journal of Money, Credit and Banking 20, pp. 409-421.

Dornbusch, R., and A. Werner (1994), Mexico: Stabilization, Reform, and no Growth, Brooking Papers on Economic Activity 1 pp. 253-297.

Dornbusch, R., G. Ilan, and R. Valdez (1995), Brooking Papers on Economic Activity, 2 pp. 219-293.

Engle, R. F. (1982), Autoregressive Conditional Heteroscedasticity with Estimates of the Variance of United Kingdom inflation, Econometrica 50, pp. 987-1007.

Engle, R. F. (1983), Estimates of the Variance of U.S. Inflation based upon the ARCH Model, Journal of Money, Credit and Banking 15, pp. 286-301.

Engle, R. F., D. M. Lillien, and R. P. Robins (1987), Estimating Time Varying Risk Premia in the Term Structure: The ARCH-M model, Econometrica 55, pp. 391-407.

Fama, E. F. (1975) Short term Interest Rates as Predictors of the Inflation, American Economic Review 65, pp.

Garcés, D. (1999), Price level Determination and the Inflationary Dynamic in Mexico, Banco de Mexico, Research document No. 9907.

Gruben, W. (1996), Policy Priorities and the Mexican Exchange Rate Crisis, Federal Reserve Bank of Dallas, First Quarter, 19-29.

Guerrero, V. (1982), The Inflationary Process in Mexico: Theory and Applications of the Intervention Analysis, Banco de Mexico, Research document No. 49.

Guerrero, V. (1984), Analysis Evaluation and Forecasting of Mexico's Inflation, Banco de Mexico, Research document No. 57. 
Hamilton, J.D., and R. Susmel, (1994), Autoregresive Conditional Heteroscedasticity and changes in Regime, Journal of Econometrics 64, pp. 307 - 333.

Hamilton, J.D. (1994) Time Series analysisis, Princeton.

Nelson, D. (1991), Conditional Heteroscedasticity in Asset Returns: A new Approach, Econometrica 59.

Schwert W. (1990), Stock Volatility and the Crash of '87, Review of Financial Studies 3, pp. 77-102. 